\title{
Level Of Perception Emergency Skills In Youth Red Cross
}

\author{
Heru Suwardianto ${ }^{1}$ \\ ${ }^{1}$ STIKES RS. Baptis Kediri, Indonesia \\ Corresponding author : herusuwardianto@gmail.com
}

\begin{abstract}
Background: The state of emergency at school is a crisis condition of an environmental or individual condition. An emergency situation can happen to anyone, anywhere, anytime. Critical patients are a condition of one or more system organ failures that are irreversible.

Purpose : The purpose of this study is to determine the level of perception emergency skills in youth red cross at Senior High School 3 Kediri City.

Methods : Research Design was descriptive analitic. The population was the students who are members of the youth red cross at the Senior High School 3 Kediri City. Sample ware 35 respondents based on inclusion and exclusion criteria using purposive sampling. The variable ware skill in performing the act of measurement of blood pressure, pulse, temperature position the victim fainted because of low blood pressure, position the victim fainted because of asthma, open wounds dressing, splinting of extremities injured or fracture, cardiopulmonary resuscitation, removing off helmet and fixation of the neck victims of traffic accidents. Measuring devices using Analog Range Scale (ARS 1-10): Skill.

Result : The results showed that the mean score of less than 5 was on the skill lift the victim fainted because of low blood pressure $(4.60 \pm 2.51)$, splinting of extremities injured or fracture $(4.77 \pm 2.52)$, cardiopulmonary resuscitation, and removing the helmets and fixation of neck victims of traffic accidents $(1.63 \pm 2.47)$. The results of the study also found that 8 groups of data had a skewness ratio of $-2 /+2$, and a group of non-distributed data on cardiopulmonary resuscitation skills (3.42), and removal of helmets and neck injuries for traffic casualties (4.77).

Conclusion : Increased preparedness with training is required in schools to reduce the risk of emergency or disaster events.
\end{abstract}

Keywords : Level of skill perception, juvenile red cross, emergency situation

How to Cite: Suwardianto, H. (2018). Level Of Perception Emergency Skills In Youth Red Cross. Journal Of Nursing Practice, 2(1), 17-24. https://doi.org/10.30994/jnp.v2i1.38 


\section{BACKGROUND}

The emergency situation is a crisis condition of an environmental or individual condition (Morton, 2013). Critical patient is a condition of failure of one system or even more irreversible (Suwardianto, Prasetyo and Utami, 2017). Helper who is unaware of emergency procedures can aggravate the victim's situation, as well as the use of personal protective equipment (Busick, 2016). The emergency treatment process should be in accordance with the procedures learned when the helper performs relief and evacuation measures (Busick, 2016). The emergency rescue team at Senior High School (SMA) is the Youth Red Cross team (PMR). The youth red cross is a helper that can reduce emergency school problems. Success in first aid is crucial to the success of further help. The youth red cross is the first line in high school to do the relief if at school there is an emergency event, so it is very important that the helper competency will be improved. The existing community in the school allows for emergency medical situations, injuries, disasters, chronic health condition complications, or major unexpected diseases occurring in schools (CSH, 2008). Schools are a safe and healthy place and environment that protects the student and staff within it from threats and dangers (REMS, 2018). If the school environment has a large risk of disaster or emergency situations it is necessary to increase the preparedness in a good school.

Disasters and emergencies are scattered all over the world. The US Geological Survey shows that 17 major earthquakes (magnitude $7.0+$ ) and one large earthquake $(8.0+$ magnitude) is expected to occur in a given year along with millions of small earthquakes around the world. While smaller earthquakes may not have much impact on schools, it is important to take precautions if a major earthquake occurs. In 2008 there were $70 \%$ of deaths from injuries occurring in school-aged children (5-19 years), an estimated $10 \%$ to $25 \%$ of injuries to children occurred while they were in school. In a survey of all high schools in the State of Washington, $80 \%$ of teachers thought that CPR training was important, but $35 \%$ of schools did not provide CPR training for students (CSH, 2008) Disaster events in Indonesia in the first half of 2016 recorded 1,121 disasters in the province of Indonesia. Tornadoes dominate 113 incidents, the impact caused 230 dead and missing, 1770 suffered and evacuated. Indonesia in 2017 there are 2,341 Disasters with the impact of the disaster of 377 people died and disappeared, and 3.5 million people suffered and evacuated. East Java province during the year 2017 there are 419 Disasters (BNPB, 2018).

Many schools lack healthcare professionals to handle individual medical emergencies. Injuries are the leading cause of death and disability, especially among students, in addition to injury-related emergencies, status of asthmatics, diabetes crisis, epilepticus status, sudden cardiac death, and other medical emergencies can occur in students and staff at school. The average school-age child spends $28 \%$ of the day and $14 \%$ of his total school hours (CSH, 2008). Emergency preparation is essential, but emergency school emergency preparedness is often inadequate due to obstacles such as the condition of geographic and physical facilities, staff, staff education and training, and financial resources. Important factors in school preparedness for emergency situations are medical, non-medical, and student training. School medical emergencies may involve students, adults, staff members, or special event participants after they have received training. Because injuries are the most common life-threatening emergency situations faced by children and adolescents inside or outside school, teachers, school nurses, doctors, athletic trainers, trainers and students should know the general principles of first aid and 
cardiopulmonary resuscitation (CPR). Meeting special health care needs that require training of personnel, equipment or even medicines and supplies, and subsequent transportation needs to be planned in the school. Initial preparedness at school that needs to be prepared is an emergency daily training. Emergency training needs to be applied in each school to increase awareness, first-aid ability, so as to increase the likelihood of safety and reduce the likelihood of disability after receiving further medical treatment after the victim has transported to the health service. Each School varies greatly in their degree of readiness to deal with emergency situations. Schools with larger communities, if less prepared to handle emergency situations in students or staff assessed by evaluating emergency equipment and training, the impact of death or disability will be greater. The importance of emergency school training in preparing for and responding to individual emergency situations. Management of individual emergency situations related to preparation for large-scale community emergency. Resources, and staff training are all very important for emergency preparedness.

\section{OBJECTIVE}

The purpose of this study is to determine the level of perception emergency skills in youth red cross at Senior High School 3 Kediri City.

\section{METHODS}

This research was uses pre-experimental-posttest design. The study population is all students who are members of the juvenile red cross in the Senior High School 3 Kediri City. The purpose of this study is to determine the level of perception emergency skills in youth red cross at Senior High School 3 Kediri City. Samples ware some of the students who are members of the youth red cross in the Senior High School 3 Kediri City, which amounted to 35 respondents. Inclusion criteria ware students who follow the youth red cross, class X or XI, exclusion criteria are the students of class XII. The sampling technique used was purposive sampling. The variable ware skill in performing the act of measurement of blood pressure, pulse, temperature position the victim fainted because of low blood pressure, position the victim fainted because of asthma, open wounds dressing, splinting of extremities injured or fracture, cardiopulmonary resuscitation, removing off helmet and fixation of the neck victims of traffic accidents. Measuring devices using Analog Range Scale (ARS 1-10): Skill. Statistical test using skweness ratio test and Distribution frequency. The research paid attention to ethical research (ethical clearance) such as autonomy, respect for person, beneficence, non-maleficence, justice, No. SPPD 0952/19 / IX / STIKES / RSBK / 2017.

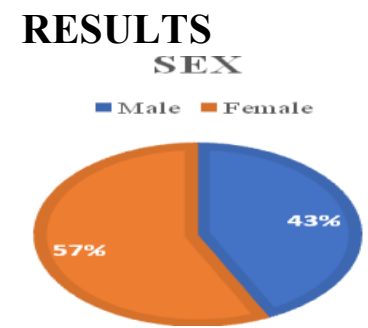

Figure 1. Distribution Frequency of Sex in Youth Red Cross at Senior High School 3 Kediri City $(\mathrm{n}=35)$ 
Based on the research results found that more than $50 \%$ of respondent's female sex of 20 respondents $(42.9 \%)$.

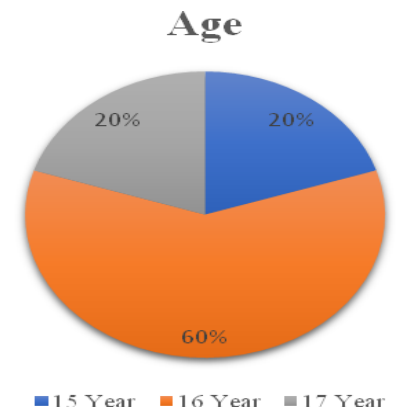

Figure 2. Distribution Frequency of Age in Youth Red Cross at Senior High School 3 Kediri City $(\mathrm{n}=35)$

Based on the results of the study found that more than $50 \%$ of respondents aged 16 years as many as 21 respondents $(60 \%)$.

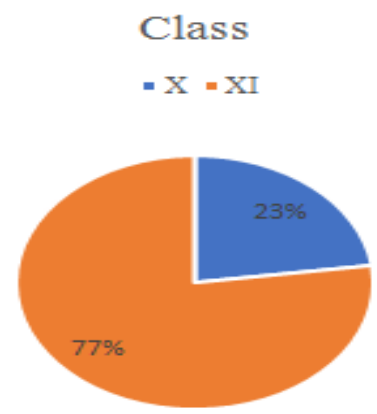

Figure 3. Distribution frequency of Class in Youth Red Cross at Senior High School 3 Kediri City $(n=35)$

Based on research results it was found that most respondents were in class XI as many as 27 respondents $(77.1 \%)$.

\section{Science}

- IPA - IPS

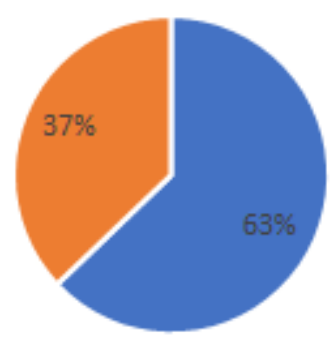

Table 4. Distribution frequency of Science in Youth Red Cross at Senior High School 3 Kediri City $(\mathrm{n}=35)$ 
Based on research results it was found that most respondents were in the science class as many as 22 respondents $(62.9 \%)$.

Table 5. Level of perception emergency skills in Youth Red Cross Youth at Senior High School 3 Kediri $(n=35)$

\begin{tabular}{|c|c|c|c|c|c|c|}
\hline \multirow{2}{*}{ No } & \multirow{2}{*}{ Perception Emergency Skills } & \multirow{2}{*}{$\begin{array}{l}\text { Mean } \\
\text { score }\end{array}$} & \multirow{2}{*}{ SD } & \multicolumn{3}{|c|}{ Skewness } \\
\hline & & & & $\mathbf{S}$ & SE & Ratio \\
\hline 1 & Measurement of Blood Pressure & 5,20 & 2,03 & $-0,42$ & 0,40 & $-1,07$ \\
\hline 2 & Measurement of Pulse Frequency & 5,57 & 1,88 & 0,08 & 0,40 & 0,20 \\
\hline 3 & Measurement of temperature & 6,11 & 2,18 & $-0,17$ & 0,40 & $-0,43$ \\
\hline 4 & $\begin{array}{l}\text { Position the victim fainted because of } \\
\text { low blood pressure }\end{array}$ & 5,71 & 2,16 & $-0,11$ & 0,40 & $-0,27$ \\
\hline 5 & $\begin{array}{l}\text { Positioning the Fainting Victim due to } \\
\text { Low Blood Pressure }\end{array}$ & 4,60 & 2,51 & 0,06 & 0,40 & 0,15 \\
\hline 6 & $\begin{array}{l}\text { Position the victim fainted because of } \\
\text { asthma }\end{array}$ & 5,40 & 2,21 & $-0,13$ & 0,40 & $-0,32$ \\
\hline 7 & open wounds dressing & 5,66 & 2,34 & $-0,29$ & 0,40 & $-0,73$ \\
\hline 8 & $\begin{array}{l}\text { splinting of extremities injured or } \\
\text { fracture }\end{array}$ & 4,77 & 2,52 & $-0,28$ & 0,40 & $-0,69$ \\
\hline 9 & Cardiopulmonary resuscitation & 1,77 & 2,14 & 1,36 & 0,40 & 3,42 \\
\hline 10 & $\begin{array}{l}\text { removing off helmet and fixation of the } \\
\text { neck victims of traffic accidents }\end{array}$ & 1,63 & 2,47 & 1,90 & 0,40 & 4,77 \\
\hline
\end{tabular}

Based on the research results obtained mean, SD and skewness. The results of the study showed that the mean score of less than 5 was on the skill positioning the fainting victim due to low blood pressure $(4.60 \pm 2.51)$, injury or fracture of the extremity $(4.77 \pm$ 2.52), cardiopulmonary resuscitation, and removing helmet and neck accident victims of traffic accidents $(1.63 \pm 2.47)$. The results of the study also found that 8 groups of data had a skewness ratio of $-2 /+2$, and a group of non-distributed data on cardiopulmonary resuscitation skills (3.42), and removal of helmets and neck injuries for traffic casualties (4.77)

\section{DISCUSSION}

The study measured 10 perceptions of emergency skills obtained 4 skills that have mean score less than 5 (range 0-10) that is on the skill positioning the fainting victim due to low blood pressure, injured or broken limb wounds, cardiac pulmonary resuscitation, and removing helmets and fixation of neck victims of traffic accidents. While the 5 skills have a mean score of less than 6 that is the measurement of blood pressure, pulse measurement, raises the fainting victim, positioned the fainting victim due to asthma, and an open wound dressing. The result of the research shows that only 1 skill that has value above 6 is temperature measurement $(6,11)$. Based on the results of the study found that more than $50 \%$ of respondents are female $(42.9 \%)$, and aged 16 years $(60 \%)$, and respondents are in class XI IPA.

Based on the result of the research, it is found that the majority of youth red cross respondents have mean skill ang less (mean score $<6$ ). Inadequate skills in students, staff, or health teams in schools in the prevention and treatment of emergency will have an 
impact on the success of saving lives or minimizing the disability of the victim during an emergency or disaster. Disaster comes in many forms, can happen anywhere, when and anyone. An emergency may occur during an earthquake, fire, accident or clinical condition that causes a person to be in an emergency. Emergency preparedness efforts and emergency plans help keep students and staff safe (Olson, 2018).

Emergency training is the development of preparedness training in the event of an emergency or daily disaster and is still a process of development in schools. The training is a process of planning assessment, physical protection and response capacity development designed to protect students and staff from physical harm, minimize disruption and ensure continuity of education for students, and develop and maintain a safety culture in schools. Emergency and school emergency preparedness requires a dynamic and sustainable process of management and involving workers, students, parents, and the local community. Disaster and emergency management in schools involves all existing sectors starting from project management: assessing hazards, vulnerabilities, capacities and resources; plan and implement for physical risk reduction, maintenance of safe facilities, standard operating procedures and training for disaster response; test plans and skills on mitigation and preparedness regularly, with realistic simulation exercises; and refine your plan based on the experience of the situation in place (Ellena, 2010). Disaster and emergency management in schools reflects disaster prevention of individuals, staff and families.

Inadequate skills in practice need to be improved so that disaster management and emergency management can be implemented as well as possible. Schools have teenage Red Cross teams that can be trained in preparing teams for prevention and preparedness in the event of an emergency. Emergency training is a learning model that is systematic, interesting, and goal-oriented learning. The EIM provides clear guidelines for identifying key concepts, strategies, skills taught. The learning methods provided in the training provide effective lesson lessons; and gives students the opportunity to practice and master new material (Archer and Hughes, 2011).

Emergency training is crucial to improving the skills of juvenile red cross respondents. Improved skills such as blood pressure measurements, pulse, temperature, lifting fainting victims due to low blood pressure, positioning fainting victims due to asthma, open wound dressing, splinting on the injured or broken limbs, resuscitation of the lung heart, removing helmets and neck injuries cross. Helper if you do not have the skills then the help becomes not qualified. The emergency nursing perspective is a complete view of an emergency nursing process that is often in contact with other multidisciplinary competencies in terms of delegation or nurse independence and by law. Nursing collaborative diagnoses should be frequently explored, studied, and researched by professional nurses (Suwardianto, 2015; Suwardianto and Richard, 2017). First aid when emergency measures are needed, promotive preventive measures are needed to increase conductivity (Suwardianto, 2013). School preparedness needs to be continuously improved with training from higher education, social institutions, or even surrounding hospitals. Increased emergency preparedness in schools will improve security and emergency response in the event of hazard or other emergency conditions. Schools should also consider the implementation of disaster management or emergency departments in their respective areas. Indonesia is one of the largest disaster supermarkets in the world. World researchers have been coming to Indonesia to do research related to disaster condition and emergency condition in Indonesia. Schools with large populations, populations gathered within a certain duration of time have the greatest potential for the most casualties during a disaster or emergency. 
Good preparedness will reduce the critical conscience of the victim when taken to the Emergency Department (IGD).

Schools and government policy makers need to think through practical risk reduction measures to reduce the impact of disasters. Stakeholders need to provide school rules and regulations that are physically and psychologically safe. Strategies need to be continually developed in school preparedness focusing on comprehensive multi-hazard emergency situations (Trump, 2018). Training focuses on risk identification and risk reduction best practices at various levels. Emergency training enhances the preparedness that is currently being developed by adolescent cross-cutting students residing in schools. Improving skills in emergency preparedness will have an impact on disaster risk reduction or emergency situations as resilience in school institutions will increase

\section{CONCLUSION}

The results of the study indicated that the mean score of less than 5 was on the skill positioning the fainting victim due to low blood pressure, injury or fracture of the extremity, resuscitation of the pulmonary heart, and removing the helmet and neck collision of the traffic accident victims. The results of the study also found that 8 groups of data had a skewness ratio of $-2 /+2$, and a group of non-distributed data on cardiopulmonary resuscitation skills (3.42), and removal of helmets and neck injuries for traffic casualties (4.77).

\section{REFERENCES}

Archer, A. L. and Hughes, C. A. (2011) Explicit Instruction; Effective and Efficient Teaching. New York, United States Of America: The Guilford Press.

BNPB (2018) Badan Nasional Penanggulangan Bencana. Available at: https://bnpb.go.id.

Busick, J. (2016) Preparedness is Prevention: Emergency Preparedness Could Have Prevented These Injuries, EHS, p. 1.

CSH (2008) Medical Emergencies Occurring at School, American Academy of Pediatrics, 122(4), p. 1.

Ellena, G. (2010) Disaster and Emergency Preparedness: Guidance for Schools. Washington DC, USA: International Finance Corporation, World Bank Group.

Morton, T. (2013) Hyperobjects: Philosophy and Ecology after the End of the World, University of Minnesota. USA: The Johns Hopkins University Press.

Olson, L. (2018) School Emergency Planning and Safety, Cal OES, Governor's Office of Emergency Services. Available at: http://www.caloes.ca.gov (Accessed: 15 May 2018).

REMS (2018) Developing Emergency Operations Plans; K-12 101 Training. US: Readiness and Emergency Management for Schools (REMS) Technical Assistance (TA) Center.

Suwardianto, H. (2013) Deep breathing relaxation as therapy to decrease blood preassure on hypertension patients, In Proceedings Faculty Of Nursing Of Airlangga The fourd Internasional Nursing Conference Improving Quality Of Nursing Care Though Nursing Research and Innovations, 1(1), pp. 1-12.

Suwardianto, H. (2015) Buku ajar keperawatan kegawatdaruratan (perspektif, konsep, prinsip, dan penatalaksanaan kegawatdaruratan). 1st edn. Surabaya: PT. REVKA PETRA MEDIA. 
Suwardianto, H. and Richard, S. D. (2017) Asuhan Keperawatan Kegawatdaruratan dan Penatalaksanaan Tindakan Kegawatdaruratan. Nganjuk: CV Adjie Media Nusantara.

Suwardianto, H., Prasetyo, A. and Utami, R. Su. (2017) Physical Function-Tardive Dyskenesia (PATD) on Critical Patients in Intensive Care Unit, Jurnal Ners, 12(2). doi: http://dx.doi.org/10.20473/jn.v12i2.4504.

Suwardianto, Heru. Prasetyo, Awal, Utami Reni Sulung (2018). Effect of Physicalcognitive Therapy (PCT) on Criticaly ill Patients in Intensive Care Unit. Hiroshima Journal of Medical Sciences Vol. 67 Spesial Issue.

Trump, K. (2018) School Security \& School Emergency / Crisis Preparedness Training School Security and Emergency Planning Training Formats and Topics, National School Safety and Security Services. Available at: http://www.schoolsecurity.org (Accessed: 15 May 2018). 